\title{
MAKNA WARNA MERAH DALAM TRADISI ETNIS TIONGHOA SEBAGAI JEMBATAN KOMUNIKASI UNTUK MEMPERKENALKAN MAKNA DARAH YESUS
}

\author{
oleh \\ ${ }^{*}$ Deky Nofa Aliyanto dan ${ }^{* 2}$ Sinta Kumala Sari \\ ${ }^{* 1}$ Dosen Sekolah Tinggi Teologia Berea Salatiga \\ ${ }^{*}$ Mahasiswa Pasca Sarjana STT Gamaliel Surakarta \\ ${ }^{* 1}$ Korespodensi penulis: dekytheo@gmail.com
}

\begin{abstract}
ABSTRAK-Berdasarkan sudut pandang iman Kristen Allah mau semua orang termasuk etnis Tionghoa di Indonesia hidup didalam kasihnya melalui karya Kristus di kayu Salib. Dalam salah satu tradisinya, Etnis Tionghoa tidak bisa dilepaskan dari warna merah. Sedangkan warna merah dalam iman Kristen diwakili dengan darah Yesus. Penelitian ini bertujuan untuk menjadikan makna warna merah dalam tradisi etnis Tionghoa sebagai jembatan komunikasi untuk memperkenalkan makna darah Yesus. Penelitian ini menggunakan metode pendekatan kualitatif dengan analisis interaktif dan kontekstualisasi. Hasil dari penelitian ini menunjukan bahwa Etnis Tionghoa dengan tradisi warna merah yang didalamnya mengandung konsep keselamatan memiliki kemiripan dengan makna teologis darah Yesus (darah berwarna merah). Berdasarkan hasil temuan ini maka makna warna merah dalam tradisi Etnis Tionghoa dapat digunakan oleh orang Kristen sebagai jembatan komunikasi untuk memperkenalkan makna darah Yesus kepada etnis Tionghoa.
\end{abstract}

Kata Kunci: Etnis Tionghoa, Warna Merah, Darah Yesus

\begin{abstract}
From the point of view of the Christian faith God wants all people, including ethnic Chinese in Indonesia to live in love through the work of Christ on the Cross. In one of its traditions, Chinese Ethnic cannot be released from red. While the red color in the Christian faith is represented by the blood of Jesus. This study aims to make the meaning of red in the Chinese ethnic tradition a communication bridge to introduce the meaning of Jesus' blood. This research uses a quantitative approach methodology with interactive analysis and contextualization. The results of this study indicate that the Chinese ethnic with the red tradition which contains the concept of salvation have similarities with the theological meaning of Jesus' blood (red blood). Based on these findings, the meaning of red in the Chinese ethnic tradition can be used by Christians as a communication bridge to introduce the meaning of Jesus' blood to Chinese etnic.
\end{abstract}

Keywords: Chinese Ethnic, Red Color, Jesus' Blood

\section{Pendahuluan}

Etnis Tionghoa di Indonesia dibedakan menjadi dua kelompok yaitu etnis Tionghoa totok dan etnis Tionghoa peranakan. Etnis Tionghoa totok adalah mereka yang baru menetap di Indonesia dengan satu atau dua generasi. Etnis Tionghoa peranakan adalah mereka yang telah menetap di Indonesia sekurangkurangnya tiga generasi atau lebih. 
Meskipun mereka telah tinggal di Indonesia namun mereka tetap melestarikan kebudayaan mereka. Orang Tionghoa totok lebih kuat dalam melestarikan tradisi yang menjadi budaya mereka dari pada Tionghoa peranakan.

Lebih jauh dapat dikemukakan bahwa pengelompokkan seperti itu didasarkan pada derajat adaptasi dan akulturasi orang-orang Tionghoa terhadap kebudayaan di sekelilingnnya. Derajat adaptasi dan akulturasi orang Tionghoa dimaksud sangat tergantung dari perpaduan (integrasi) dan pembauran (asimilasi) orang-orang Tionghoa dengan penduduk pribumi serta jumlah angkatan (generasi) yang telah ada di Nusantara. ... Bahkan di antara mereka yang telah melakukan asimilasi pun masih ada yang menganggap dirinya sebagai orang Tionghoa. ${ }^{1}$

Kebudayaan yang dilestarikan mencakup materi dan non materi. Diantaranya adalah sistim kepercayaan, orang-orang Tionghoa menganut kepercayaan dari leluhur yaitu Khong $\mathrm{Hu}$ $\mathrm{Cu}$ walaupun ada diantara mereka yang juga menganut kepercayaan atau agama yang di akui di Indonesia. Etnis Tionghoa juga masih memperingati perayaan hari raya seperti Tahun Baru Imlek, Ceng Beng (bersih kubur leluhur), hari raya Toan Yang atau Phecun yang identik dengan makan bahcang (beras/ketan yang berisi dading babi dan di bungkus dengan daun bambu) atau kue cang (ketan yang dibungkus daun bambu yang dimakan dengan gula atau sirup). "Hari raya sembahyang Cioko (mirip dengan hari Hollowen yang dilakukan di dunia Barat),

${ }^{1}$ Chris Hartono, Orang Tionghoa Dan Pekabaran Injil, (Yogyakarta: Penerbit Taman Pustaka Kristen, 1996), 4. hari raya pertengahan musim rontok yang identik dengan tong ciu pia atau kue bulan, hari raya Tang $\mathrm{Ce}$ yang menandakan musim dngin tiba, identik dengan makan onde-onde atau ronde." "Selain itu, etnis Tionghoa totok masih memberikan nama untuk anak-anak dan cucu mereka dengan nama Tionghoa misalkan penulis dengan nama Sinta memiliki nama Tionghoa: Lie Woen $\mathrm{Cu}$. Ada juga sebagian dari nama marga mereka diselipkan dengan nama Indonesia, misalnya marga Lie menjadi nama Indonesia:Liesianto." 3

Ada banyak simbol-simbol yang memiliki arti tersendiri juga menjadi ciri khas bagi etnis Tionghoa dan dijumpai secara umum. Seperti lukisan ikan koi, patung kucing duduk dengan tangan yang melambai, lampion dan sebagainya. Selain itu beberapa warna juga menjadi warna yang khas bagi mereka, seperti warna: Putih, Biru, Hijau, Emas, Merah dan sebaginya. Namun dari semua warna tersebut yang paling dominan yaitu warna Merah sebagai lambang kebahagiaan. Oleh sebab itu warna merah sering dijumpai dalam kehidupan mereka, terutama dalam perayaan-perayaan. ${ }^{4}$ Warna merah dalam perayaan-perayaan diwujudkan dalam berbagai bentuk seperti makanan, kain, pakaian, kertas atau amplop dan sebagainya. Menarik untuk mempelajari warna merah karena memiliki peranan tersendiri dalam tradisi etnis Tionghoa yang dapat dijadikan sebagai jembatan komunikasi memperkenalkan makna darah Yesus kepada mereka.

\section{Rumusan Masalah}

Bagaimana makna warna merah dalam tradisis etnis Tionghoa dapat digunakan orang Kristen sebagai jembatan

\footnotetext{
2 Ibid, 7.

${ }^{3}$ Contoh perubahan nama tersebut berdasarkan latar belakang keluarga besar penulis yang masih kental memegang tradisi Tionghoa.

${ }^{4}$ Markus T. Suryanto, Feng shui/Hong Sui Dan Orang Kristen, (Jakarta:Pelayanan Literatur Kristen Indonesia, 1995), 94.
} 
komunikasi untuk memperkenalkan makna darah Yesus kepada etnis Tionghoa?

\section{Tujuan Dan Manfaat Penelitian}

Penelitian ini bertujuan untuk menemukan makna warna merah dalam tradisi etnis Tionghoa sehingga dapat digunakan orang Kristen sebagai jembatan komunikasi untuk memperkenalkan makna darah Yesus kepada etnis Tionghoa. Manfaat dari penelitian ini adalah: Secara teoritis penelitian ini diharapkan memberikan kontribusi ilimiah pada kajian misiologi kontekstual. Secara praktis orang Kristen dapat menggunakan hasil penelitian ini sebagai jembatan komunikasi atau menyusun pendekatan memperkenalkan makna darah Yesus kepada etnis Tionghoa.

\section{Metode Penelitian}

Penelitian ini menggunakan metodologi pendekatan kualitatif. ${ }^{5}$ Sumber data didapatkan dari studi Alkitab dan literatur yang terdiri dari buku-buku, internet, artikel, serta data tertulis lain yang berkaitan dengan penelitian ini. ${ }^{6}$ Analisis yang digunakan adalah analisis interaktif yang mencakup: Pertama, pengumpulan data. Kedua, penyajian data. Ketiga, reduksi data dan Keempat, penarikan kesimpulan. ${ }^{7}$ Penelitian ini juga melibatkan pendekatan kontektualisasi yaitu kontekstualisasi rasuli yang menerangkan (menerjemahkan, menafsirkan, mengadaptasi, menerapkan) iman yang sekali dan untuk selamanya dipercayakan kepada orang-orang Kudus kepada orang dari budaya-budaya lain,

\footnotetext{
${ }^{5}$ Stevri Indra Lumintang dan Danik Astuti Lumintang, Theologia Penelitian dan Penelitian Theologis Science-Ascience serta Metodologinya, (Jakarta: Geneva Insani Indonesia, 2016), 23.

${ }^{6}$ Andreas S.Subagyo, Pengantar Riset Kuantitatif dan Kualitatif, (Bandung: Yayasan Kalam Hidup, 2004), 161-162.

${ }^{7}$ M. B Miles \& Huberman, A. M. Qualitative Data Analysis: A Sourcebook of New (California. Sage Publication Inc, 1984), 23.
}

begitu rupa hingga melestarikan sebanyak mungkin makna dan relevansi aslinya. ${ }^{8}$

\section{Tinjauan Warna Merah Dan Maknanya Dalam Tradisi Tionghoa}

Warna Merah Dalam Perayaan Tahun Baru Imlek

Tahun baru Imlek disebut pesta musim semi karena penanggalannya mempunyai hubungan dengan alam yang berketepatan dengan musim semi. Etnis tionghoa beranggapan bahwa tahun baru Imlek berarti pergantian keadaan mati selama musim dingin kepada awal kehidupan alam semesta yang ditandai dengan musim semi. Para sastrawan Tiongkok melukiskan musim semi yang serba merah yang dikaitkan dengan keberuntungan. Warna merah menghiasi seluruh perayaan Imlek mulai dari asesoris, pakaian, hiasan dan juga Ang Pao/Hung Bao yaitu amplop merah yang berisi uang.

Satu hari sebelum perayaan tahun baru Imlek akan diadakan sembahyang Sam Seng (tiga hewan, yaitu babi, ayam dan ikan bandeng) dan Ngo Seng (lima hewan, tiga hewan sam seng ditambah bebek dan kepiting). Dalam sembahyang tersebut disajikan berbagai makanan yang ditutup dengan kertas minyak yang berwarna merah dan pada makanan basah ditancamkan sekuntum bunga warna merah yang terbuat dari kertas berwarna merah. Diletakkan di atas meja dengan taplak meja yang berwarna merah dengan gambar binatang naga, bunga dan seorang petapa, serta sepasang lilin berwarna merah yang diletakkan di sisi kiri dan kanan meja. Sembayang tersebut diadakan

${ }^{8}$ David J. Hesselgrave \& Edward Rommen, Kontekstualisasi: Makna, Metode dan Model (Jakarta: BPK GUnung Mulia, 2006), 183. 
selain untuk menghormati para leluhur juga memiliki makna adanya hewan yang dikorbankan dan pencurahan darah. Darah yang dicurahkan diwakili dengan warna merah membawa keselamatan, perlindungan, rejeki dan kebahagiaan. ${ }^{9}$

Ciri khas lain dari perayaan Imlek adalah pemberian Ang Pao atau Hung Bao yaitu bungkusan merah atau amplop merah. Ang Pao tidak hanya diberikan pada saat hari raya Imlek saja tetapi pada acara-acara tertentu seperti acara Shang Jit (lamaran), perayaan ulang tahun dan pernikahan. Ang Pao dipercaya melindungi rejeki dan uang yang ada di dalamnya dianggap sebagai bibit rejeki. Oleh sebab itu, seringkali Ang Pao tidak dibuka tetapi disimpan di dalam laci uang. Bukan soal jumlah uangnya, tetapi justru Ang Pao ini dianggap sebagai Wie Sit atau pembawa rejeki. ${ }^{10}$

Perayaan Imlek juga dimeriahkan dengan petasan. Petasan dibungkus dengan kertas warna merah, rencengan petasan seluruhnya berwarna merah. Petasan di bakar di halaman rumah pada malam tahun baru Imlek. Serpihan kertas warna merah dari petasan tersebut akan berserakan di halaman rumah dan dipercaya membantu pemilik rumah hidup bahagia dan berkecukupan di tahun yang baru. Warna merah mendominasi seluruh perayaan Imlek yang memberikan arti keselamatan dengan adanya korban darah, pembawa rejeki dan kebahagiaan.

Warna Merah Dalam Upacara Pernikahan Warna merah mendominasi dalam upacara pernikahan etnis Tionghoa mulai dari kartu undangan, pakaian mempelai, dan dekorasi. Kartu undangan pernikahan

${ }^{9}$ Markus T. Suryanto, Imlek Budaya Tionghoa dan Iman Kristen, (Jakarta: Pelkrindo, 1999), 76

${ }^{10}$ Markus T, Suryanto, Feng shui/Hong Sui Dan Orang Kristen. (Jakarta:Pelayanan Literatur Kristen Indonesia, 1995), 99. mereka pasti dibuat dengan warna merah darah yang memilki arti kebahagiaan bagi seluruh keluarga. Pakaian mempelai berwana merah dengan sulaman gambar bunga yang dibuat dari benang emas. Bagi yang masih memegang tradisi ada satu upacara yang bernama Cio Tao dilaksanakan pada pukul lima pagi atau pukul dua belas atau satu malam. Upacara ini dilakukan bagi pasangan yang masih suci, perawan dan perjaka.

Cio Tao merupakan peristiwa besar dan kaya dengan simbol-simbol, dengan prosedur sebagai berikut: mempelai duduk di sebuah tetampa berarti dunia, dihadapannya diletakkan gentong kecil, cermin sarana untuk memeriksa diri, beras kecukupan dalam berumah tangga, gambar Pat Kwa untuk mengingatkan asalusul manusia, benang 7 warna melambangkan kewajiban seorang isteri, pokiam/pedang mengingatkan suami untuk membela isteri dan melindungi rumah tangganya bersifat ksatria dan tidak menyeleweng, gunting untuk memutuskan benang-benang kusut dalam rumah tangga dengan kerendahan hati dan ketulusan serta saling memafkan, pelita supaya ada penerangan dalam rumah tangga khususnya dalam batin suami dan isteri, timbangan mengingatkan supaya bersifat adil dalam memutuskan hal-hal yang ada 
dalam rumah tanggadan sisir. ${ }^{11}$

Selain itu di depan pintu rumah atau kamar pengantin selalu dipasang selendang atau kain merah yang dipercaya dapat menolak malapetaka, gangguan atau kuasa si jahat yang ingin menggangu malam pengantin. Karena malam pengantin sangat menentukan masa depan yang penuh dengan kebahagiaan. Selendang merah juga digunakan pada saat peresmian toko/kantor.

Warna Merah Dalam Kelahiran, Usia Sebulan atau Ulang Tahun

Warna merah dalam acara kelahiran baik usia bayi satu bulan maupun perayaan ulang tahun. Yang menjadi ciri khas ialah telur rebus yang berwarna merah dan kue-kue yang berwarna merah seperti kue mangkok, kue ku dan seekor ayam panggang atau rebus. Dan kado yang diberikan juga ditempel Ang Pao. Maknanya adalah diberikan kebahagiaan hidup. ${ }^{12}$

\section{Warna Merah Dalam Dukacita}

Warna merah dalam dalam suasana duka diberikan untuk para pelawat sebagai ucapan terimakasih. Biasanya dalam bentuk permen yang diikat dengan benang merah, kertas putih yang digulung atau diikat dengan benang merah atau sepasang lilin merah. Bagi para pelawat yang mengantarkan sampai ke pemakaman biasanya diberi sepsang lilin merah yang diikat dengan pita merah. Apabila yang meninggal telah mencapai usia 100 atau lebih maka ketika selesai pemakaman keluarga mengganti kostum dari memakai warna putih ke warna merah. Warna merah dalam suasana ini memiliki makna sebagai warna bahagia dan sebagai tolak

\footnotetext{
${ }^{11}$ Ibid, 101.

12 Ibid, 102.
}

bala atas pengaruh yang tidak baik dari sang maut. ${ }^{13}$

\section{Tinjauan Makna Darah Yesus}

Makna Teologis Darah Yesus Dalam Keselamatan Manusia

Menurut Rasul Petrus dalam 1

Petrus 1: 18-19 tindakan penebuasan orang Kristen dari cara hidup yang sia-sia yang diwarisi dari nenek moyang bukan dengan barang yang fana, perak atau emas melainkan dengan darah Kristus yang mahal seperti darah anak domba yang tidak bernoda dan tidak bercacat. Kata "mahal" dalam bahasa Yunani adalah

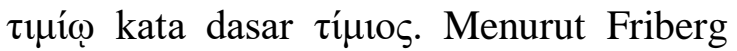
kata $\tau i ́ \mu 10 \varsigma$ secara metaforis berarti kualitas layanan seseorang. Secara kiasan, merupakan kehormatan dan nilai yang dikaitkan dengan sesuatu yang berharga, sangat berharga, yang dijunjung tinggi. ${ }^{14}$ Sedangkan menurut Gingrich kata tífos memiliki arti "berharga, berharga, mahal, sangat berharga atau bernilai yang diadakan diadakan untuk menghormati, dihormati." 15 Dengan kata lain pengorbanan Tuhan Yesus dengan pencurahan darah menunjukan kualitas pelayanan yang sangat berharga diadakan untuk menghormati manusia dan supaya manusia juga menghormati-Nya. Itulah makna bahwa darah Yesus adalah darah yang mahal.

Kata ditebus menggunakan $\lambda v \tau \rho o ́ \omega$ yang berarti membebaskan dengan menggunakan analogi penebusan seorang

${ }^{13}$ Ibid,

${ }^{14}$ Timothy Friberg and Barbara Friberg. Analytical Greek New Testament (GNM). 2nd ed. Timothy and Barbara Friberg, 1994. BibleWorks, v.10.

${ }^{15}$ F. Wilbur Gingrich, Shorter Lexicon Of The Greek New Testament. 2nd ed. Frederick W. Danker (Chicago: University of Chicago Press, 1983), BibleWorks. v.10. 
hamba. ${ }^{16}$ Matius 20:28 "sama seperti Anak Manusia datang bukan untuk dilayani, melainkan untuk melayani dan untuk memberikan nyawa-Nya menjadi tebusan bagi banyak orang." Tebusan berarti suatu harga yang dibayar untuk memperoleh kebebasan seorang. Dalam karya penebusan Kristus, kematian-Nya merupakan harga yang dibayar untuk membebaskan manusia dari kuasa dosa. ${ }^{17}$ Harga yang dibayarkan dalam konsep penebusan Yesus Kristus adalah dengan mencurahkan darah-Nya, darah dalam arti harafiah yaitu darah dari seorang manusia, sama seperti konsep pencurahan darah pada peristiwa Paskah dalam Keluaran 12.

Darah Yesus Kristus adalah bukti yang terlihat dari kematian-Nya yang menebus manusia dari dosa. Pemahaman darah Yesus dalam Perjanjian Baru mencakup: Pertama, darah perjanjian. Yesus menunjuk kepada darah-Nya sebagai darah perjanjian yang ditumpahkan bagi banyak orang (Markus 14:24; Matius 26:28). Darah perjanjian memiliki makna bahwa darah Yesus adalah sebuah ketentuan yang telah ditetapkan untuk menebus manusia dari dosa sesuai dengan pernyataan kehendak Allah. Kedua, persembahan dan korban. Paulus mengatakan bahwa pengorbanan Yesus adalah sebagai persembahan dan korban yang harum bagi Allah (Efesus 5:2). Korban yang dimaksudkan adalah korban secara khusus yang ditegaskan dalam 1 Korintus 5:7 "Sebab anak domba Allah kita juga telah disembelih, yaitu Kristus. Ketiga, darah yang mahal. Petrus menggambarkan pengorbanan darah Yesus seperti darah anak domba yang tak bernoda dan tak bercacat (1 Petrus 1:19). Darah yang mahal berarti darah yang bernilai tinggi, sangat dihormati dan sangat langka.

${ }^{16}$ Hasan Susanto, Perjanjian Baru Interlinier Yunani Indonesia dan Konkordansi Perjanjian Baru Jilid II, (Jakarta: LAI, 2004), 496. ${ }^{17} \mathrm{http}$ ://alkitab.sabda.org/passage.php?passa ge=Mat\%2020:28,1Kor\%206:20
Pemahaman mengenai darah Yesus dapat disimpulkan bahwa Yesus Kristus telah ditentukan dari semula oleh Allah untuk menjadi Penebus umat manusia dari dosa dan pengorbanan-Nya di kayu salib merupakan persembahan dan korban yang berkenan kepada Allah. Darah yang dicurahkan adalah sangat langka, hanya Yesus saja tidak ada yang lain. Dengan demikian darah Yesus memiliki makna sebagai korban pengganti untuk menebus manusia dari dosa.

Kematian Kristus adalah
"hukuman" karena di
dalamnya Yesus menanggung
penghukurnan saat ia mati.
Kematian-Nya adalah "sub-
stitusi" karena di dalamnya
Yesus merupakan pengganti
bagi kita saat Ia mati Teori ini
sering disebut "vicarious
atonement" (penebusan yg
dilakukan utk org lain).
Seorang "Vicar" adalah
seseorg yg berdiri di tempat
org lain atau mewakili org
lain. Kematian Kristus adalah
"vicarious" karena Yesus
berdiri di tempat kita dan
mewakili kita. Sebagai
representasi,
mengambil penghukuman yg
harusnya kita alami. ${ }^{18}$

Alkitab menunjukan signifikansi dari darah Yesus yang telah tercurah yaitu: 1) Darah-Nya mengampuni dosa semua orang yang bertobat dan percaya (Mat 26:28). 2) Darah-Nya menebus semua orang percaya dari kuasa Iblis dan kejahatan (Kis 20:28; Ef 1:7; 1Pet 1:18-19; Wahy 5:9; 12:11). 3) Darah-Nya membenarkan semua orang percaya kepada-Nya (Rom $3: 24-25)$. 4) Darah-Nya menyucikan hati nurani orang-orang percaya sehingga mereka dapat melayani Allah tanpa

${ }^{18}$ Deky Nofa Aliyanto, Diktat Dogma II Antropologi, Hamartiologi, Kristologi dan Sotereologi, (Salatiga: STT Berea, 2018), 45-46. 
kesalahan dengan penuh keyakinan (Ibr 9:14; Ibr 10:22; 13:18). 5) Darah-Nya menyucikan umat Allah (Ibr 13:12; 1Yoh 1:7-10). 6) Darah-Nya membuka jalan bagi orang-orang percaya untuk langsung menghampiri Allah melalui Kristus untuk memperoleh kasih karunia, kemurahan, pertolongan, dan keselamatan (Ibr 7:25; 10:19; Ef 2:13,18). 7) Darah-Nya adalah jaminan untuk semua janji dari perjanjian baru (Ibr 10:29; 13:20; Mat 26:28; 1Kor 11:25). 8) Kuasa darah Kristus yang menyelamatkan, mendamaikan, dan menyucikan itu senantiasa tersedia untuk orang-orang pada waktu mereka menghampiri Allah melalui Kristus (Ibr 7:25; 10:22; 1Yoh 1:7). Tidak hanya itu darah Kristus secara exclusive menunjuk kepada penghapusan kesalahan Juridis kita. Hal ini berarti:

Dengan darah Yesus, hati nurani kita dibersihkan (lbr. 9: 14). Kita mendapat access/jalan masuk kepada Allah dalam penyembahan dan doa (Ibr. 10: 19). Kita secara progresif dibersihkan dari dosa yg tersisa (I Yoh. 1 :7; Why 1 :5). Kita dapat mengalahkan pendakwa2 saudara2 kita (Why 12:

I 0-11 ). Kita diselamatkan dari hidup kita yg berdosa (I Pet. 1: 1819). Ada koneksi/hubungan yang je1as dalam Alkitab antara darah Yesus dengan banyak pengorbanan dalam PL yg meliputi pengorbanan binatang. Semua pengorbanan dalam PL menunjuk kepada dan merupakan prefigure dari kematian Kristus. ${ }^{19}$

Rasul Paulus menjelaskan bahwa keselamatan karena anugerah Allah melalui pencurahan darah Kristus dapat dialami oleh manusia ketika ada pengakuan dari mulut. Roma 10:9-10 "sebab jika kamu mengaku dengan mulut" bahwa Yesus adalah Tuhan, dan percaya

\footnotetext{
${ }^{19}$ Ibid, 45
}

dalam hati bahwa Kristus sudah dibangkitkan dari kematian oleh Allah maka kita akan beroleh keselamatan. Ayat ini menyebutkan apa yang kita harus lakukan dengan mulut dan hati kita. Urutan mulut dulu, baru hati mencerminkan urutan dalam Ulangan 30:14. "Mengaku dengan mulut" dalam bahasa Yunani adalah o`mologh,sh|j evn tw/l sto,mati, "mengaku" yaitu o`mologh,sh|j adalah kata kerja aorist aktif orang ke dua tunggal dari akar kata o`mologe.w yang berarti: menjanjikan, mengakui, mengaku, berkata terus terang. Sedangkan kata sto,mati, berasal dari kata benda sto,ma yang berarti: mulut atau perkataan. Oleh sebab itu "mengaku dengan mulut" bisa diperdalam artinya dengan "mengaku dengan terus terang melalui mulut, sampai pengakuan tersebut dapat didengar, bahwa Yesus adalah Tuhan. Dalam ayat 13 Paulus menegaskan "sebab, barangsiapa yang berseru kepada nama Tuhan, akan diselamatkan. "Berseru" dalam bahasa Yunani adalah evpikale,shtai dari akar kata evpikale,w yang berarti menyebut, berseru kepada, naik banding kepada, memohon kepada. Jadi pengakuan dengan mulut adalah tindakan aktif yang bersifat verbal dan dapat didengar.

"Percaya dalam hati" dalam Bahasa Yunani adalah pisteu,sh|j evn th/| kardi,a| "percaya" yaitu pisteu,sh $\mid \mathrm{j}$ adalah kata kerja aorist aktif orang ke dua tunggal dari akar kata pisteu,w yang berarti: dengan memiliki iman. Sedangkan kata kardi,al berarti: Hati. "Hati dapat menunjuk pusat kehidupan fisik manusia. Ia juga dapat menunjuk tempat dan sumber kehidupan dalam diri manusia untuk berpikir, merasa, mengambil keputusan baik secara umum dan moral." 20 Oleh sebab itu "percaya dalam hati" bisa diartikan juga dengan

${ }^{20}$ Hasan Sutanto, M.Th. Parjanjian Baru Interlinier Yunani Indonesia, Konkordansi Parjanjian Baru Jilid II, (Jakarta: lembaga Alkitab Indonesia 2004), hal 82. 
percaya mengambil keputusan bahwa Kristus telah dibangkitakan oleh Allah dari kematian maka kamu akan diselamatkan. Konsep keselamatan dalam ayat ini adalah keselamatan yang sudah berulang kali disebut dalam Surat Roma, yaitu keselamatan dari murka Allah yang saat ini sudah dinyatakkan. Konsep ini sesuai dengan seluruh Surat Roma. Jika bangsa Israel, dan kita juga, mengaku Tuhan Yesus dengan mulut dan percaya kepadaNya dalam hati, maka mereka, dan kita, akan diselamatkan atau diluputkan dari murka Allah yang saat ini "sedang dinyatakan dari surga atas segala kefasikan dan kelaliman manusia" (Roma 1:18).

Implikasi dari dua unsur yaitu mengaku dengan mulut dan percaya dalam hati terhadap Kristus, Rasul Paulus jelaskan dalam ayat selanjutnya. "karena dengan hati orang percaya "dibenarkan" 21 dan dengan mulut orang mengaku diselamatkan. Karena kitab suci berkata: barangsiapa yang percaya kepada Dia tidak akan dipermalukan." Tidak dipermalukan dalam bahasa yunani adalah kataiscunqh,setai kata kerja future indikatif pasif orang ketiga tunggal, dari akar kata kataiscunw yang berarti menghina, mempermalukan dan mengecewakan. Jadi bisa juga diartikan tidak akan dihina atau dikecewakan.

\footnotetext{
${ }^{21}$ Dibenarkan dalam bahasa Yunaninya adalah dikaiosu, nhn Kata ini dapat diterjemahkan adil atau benar. "Konsep ini berakar dari PL. Kebenaran (tsedeg, tsedeqa). Pengertian dasar istilah itu menunjukan "aturan dalam urusan dunia yang patut ditaati oleh manusia atau hal lain, dan yang menjadi tolok ukur bagi mereka. Orang yang benar adalah manusia yang mematuhi aturan yang ada. Kata kerja "menjadi benar" berarti mematuhi aturan yang ada, dan dalam bentuk tertentu, berarti "menyatakan benar" atau " membenarkan. Hal yang merupakan pukulan khususnya bagi orang Yahudi mengeneai doktrin ini adalah: seharusnya orang berdosa itu patut menerima hukuman tetapi dibenarkan oleh Allah (Roma 4;5)." Gerge Eldon Ladd, Teologi Perjanjian Baru Jilid 2, (Bandung: Yayasan Kalam Hidup, 1999), hal 189,191.
}

Roma 10:12-13 Sebab tidak ada perbedaaan antara orang Yahudi dan orang Yunani. Karena, Allah yang satu itu adalah Tuhan dari semua orang, kaya bagi semua orang yang berseru kepada-Nya. Sebab, barangsiapa yang berseru kepada nama Tuhan, akan diselamatkan. Ayat ini sebenarnya menegaskan suatu seruan kepada orang Yahudi untuk meninggalkan jalan hukum Taurat dan menerima jalan karunia. Suatu seruan kepada mereka untuk melihat, bahwa ketekunan mereka tidak pada tempatnya. Suatu seruan untuk mendengar kepada suara nabi-nabi yang sejak dahulu telah menyatakan, bahwa iman adalah satu-satunya jalan kepada Allah, dan bahwa jalan itu terbuka bagi setiap orang. Termasuk juga orang-orang etnis Tionghoa. Justru pemahaman dan kepercayaan tertentu terhadap warna merah dapat menjadi jalan menjelasakan makna darah Yesus sehingga mereka bisa dituntun untuk mengaku dengan mulut dan percaya dalam hati bahwa Yesus adalah Tuhan dan Juruselamat.

\section{Makna Warna Merah Dalam Tradisi Etnis Tioghoa Sebagai Jembatan Komunikasi Untuk Memperkenalkan Makna Darah Yesus}

Warna merah memiliki makna yang sangat penting bagi etnis Tionghoa. Terbukti dari penggunaaan warna merah dalam setiap moment memiliki makna keselamatan, kebahagiaan dan berkat atau rejeki. "Warna Merah melambangkan kegembiraan, harapan, keberuntungan dan kebahagiaan." 22 "Tanpa disadari di kalangan orang Tinghoa, sebelum mereka mengenal Kristus, mereka sudah mengerti bahkan yakin bahwa darah, baik yang

\footnotetext{
${ }^{22}$ Moedjiono, Ragam Hias dan Warna Sebagai Simbol Dalam Arsitektur Cina. Modul Volume 11. No 1. 2011.https://www.academia.edu/25718148/RAGA M_HIAS_DAN_WARNA_SEBAGAI_SIMBOL_ DALAM_ARSITEKTUR_CINA. Diakses tanggal 6 September 2019 jam 09:37 Wib.
} 
dipersembahkan melalui sembahyang Sam Seng dan Ngo Seng ataupun diwakili dengan warna merah membawa keselamatan, perlindungan, rejaki dan kebahagiaan."23 Dengan pencurahan darah dari hewan-hewan tersebut mereka menyadari bahwa untuk keselamatan perlu ada pencurahan darah dimana darah berwarna merah.

$$
\text { Konsep tersebut memiliki }
$$

kesamaan dengan konsep keselamatan dalam Perjanjian Lama yang berkaitan dengan darah. Kejadian 3: 21. Pencurahan darah hewan pertama kali terjadi setelah peristiwa manusia jatuh dalam dosa. Tuhan Allah membuat pakaian dari kulit binatang untuk manusia dan untuk isterinya itu, lalu mengenakannya kepada mereka.

Menurut Park, hal tersebut bertujuan supaya menunjukkan kepada kita bahwa manusia akan diselamatkan dengan cara kepadanya dikenakan keselamatan Kristus seperti kepadanya dikenakan pakaian. Ayat ini melambangkan bahwa Adam sendiri akan diselamatkan seperti itu. Pada saat itu binatang dibunuh sebagai korban penghapusan. ${ }^{24}$

Keluaran 12. Pencurahan darah sebagai lambang keselamatan terjadi pada saat proses keluarnya bangsa Israel dari perbudakan di Mesir. Sebelum tulah ke sepuluh, bangsa Israel merayakan Paskah. Paskah atau Pesakh dalam bahasa Ibrani berasal dari kata kerja yang berarti melewatkan dengan makna menyelamatkan. ${ }^{25}$ Tuhan Allah berfirman supaya masing-masing keluarga dari bangsa Israel mempersiapkan domba atau kambing yang akan disembelih dan

${ }^{23}$ Markus, 110.

${ }^{24}$ Yune Sun Park, Tafsiran Kitab Kejadian, (Batu: Dept. Literatur YPPII, 2002), 35.

${ }^{25} \ldots$ _ Ensiklopedi Alkitab Masa Kini

Jilid II, (Jakarta: Yayasan Komunikasi Bina

Kasih/OMF, 2002), 205. mengambil darahnya untuk dibubuhkan pada kedua tiang pintu dan pada ambang atas. Darah tersebut menjadi tanda bagi bangsa Israel bahwa tulah kesepuluh yaitu kematian anak sulung baik dari manusia maupun hewan peliharaan orang-orang Mesir hanya akan menimpa bangsa Mesir. Setiap rumah yang ada tanda darah dari orang Israel akan selamat dari tulah kematian tersebut. Sejak itu Paskah menjadi peringatan yang dirayakan oleh bangsa Israel secara turun-temurun dengan memberikan korban persembahan yang lebih bersifat pribadi. Selanjutnya peraturan mengenai pencurahan darah hewan sebagai korban $^{26}$ diatur dengan detail dan rinci dalam kitab Imamat dan menjadi suatu ketetapan bagi bangsa Israel turun temurun. Maksud korban persembahan dalam Imamat sering dinyatakan untuk menebus, menggunakan kata Ibrani kofer yang berarti menebus dengan suatu pengganti. ${ }^{27}$

Korban pencurahan darah menjadi sempurna di dalam karya Yesus di kayu salib. Penulis kitab Ibrani dengan jelas mengatakan bahwa korban Yesus sempurna dalam arti sekali untuk selamanya. Ibrani 7:27,10:14 “.....yang tidak seperti imam-imam besar lain, yang setiap hari harus mempersembahkan korban untuk dosanya sendiri dan sesudah itu barulah untuk dosa umatnya, sebab hal itu telah dilakukan-Nya satu kali untuk

${ }^{26}$ Ada banyak istilah yang digunakan untuk melukiskan jenis-jenis korban pertama, dari bentuk kata korban seperti: zevakh (korban), 'yang disembelih' (zavakh), dan ola (korban bakaran),'yang membumbung ke atas'. Kedua, dari maksudnya seperti asyam (korban penebus salah), untuk kesalahan dan khatta't (korban penghapus dosa), untuk dosa. Sedangkan korban bukan darah seperti korban sajian (minkha), buah sulung (resyit, bikkurim), berkas 16 Nisan, adonan pesta Minggu dan zakat. Ensiklopedi Alkitab Masa Kini Jilid I, (Jakarta: Yayasan Komunikasi Bina Kasih/OMF, 2002), 572.

27 Ensiklopedi Alkitab Masa Kini

Jilid I, (Jakarta: Yayasan Komunikasi Bina Kasih/OMF, 2002), 579. 
selama-lamanya, ketika Ia mempersembahkan diri-Nya sendiri sebagai korban..... Sebab oleh satu korban saja Ia telah menyempurnakan untuk selama-lamanya mereka yang Ia kuduskan."

Karya penyelamatan Kristus sering kali dibicarakan dalam pengertian etis, kadang-kadang pidana maupun korban persembahan. Kristus dikatakan Domba Allah yang disembelih, darahnya yang suci meniadakan dosa dunia (Yoh : 29; 36; 1 Ptr 1: 18; Why 5: 6-0; 13: 8). Lebih khusus lagi, Ia dikatakan Domba Paskah yang sesungguhnya (Paskha, 1 Kor 5: 6-8). Dalam Ibrani 9-10 Ia disebut penggenapan koban perjanjian dari Kel 24, lembu jantan muda berwarna merah yang disebut di Bil 19 dan Korban-korban pada hari raya pendamaian. ${ }^{28}$

Warna merah dalam tradisi etnis Tionghoa dan konsep keselamatan dalam Perjanjian Lama lebih baik dipahami sebagai bayangan atau tipologi dari penebusan Kristus di kayu salib. "Tipologi adalah suatu korespodensi dalam satu atau beberapa aspek antara tokoh, peristiwa, benda dan lain-lain dalam Perjanjian lama dengan tokoh, peristiwa, benda dan lainlain dalam Perjanjian Baru." 29 Atau dengan bahasa lain: "tipe adalah suatu bayangan dari suatu kebenaran yang terdapat dalam Perjanjian Lama, sedangkan Perwujudannya, yaitu antitipe yang terdapat dalam Perjanjian Baru."30 Warna merah dalam tradisi etnis Tionghoa yang memiliki makna keselamatan, kebahagiaan, berkat, rejeki, kegembiraan, keberuntungan dan harapan merupakan tipe atau bayangan kebenaran yang belum sempurna. Sedangkan antitipe atau penyempurnaan dari bayangan tersebut

${ }^{28}$ Ibid, 581.

${ }^{29}$ Icwei G. Indra, Allah-Manusia Sejati: Studi Ringkas Kristologi (Semarang: Pelayanan Kristen Mandiri "Mikhael"), 25.

${ }^{30}$ Ibid,. tergenapi di dalam Kristus dengan darah yang kudus dan mahal yang akan membawa kepada kebahagian sejati. Kebahagian sejati itu mencakup: DarahNya mengampuni dosa semua orang yang bertobat dan percaya. Darah-Nya menebus semua orang percaya dari kuasa Iblis dan kejahatan. Darah-Nya membenarkan semua orang percaya kepada-Nya. DarahNya menyucikan hati nurani orang-orang percaya sehingga mereka dapat melayani Allah tanpa kesalahan dengan penuh keyakinan. Darah-Nya menyucikan umat Allah. Darah-Nya membuka jalan bagi orang-orang percaya untuk langsung menghampiri Allah melalui Kristus untuk memperoleh kasih karunia, kemurahan, pertolongan, dan keselamatan. Darah-Nya adalah jaminan untuk semua janji dari perjanjian baru. Kuasa darah Kristus yang menyelamatkan, mendamaikan, dan menyucikan itu senantiasa tersedia untuk orang-orang pada waktu mereka menghampiri Allah melalui

Kristus.

\section{Kesimpulan}

Warna merah memiliki peranan yang sentral dalam kehidupan etnis Tionghoa. Warna merah memiliki makna keselamatan, perlindungan kebahagiaan dan kesuksesaan. Konsep keselamatan dengan simbol warna merah melambangkan warna darah. Etnis Tionghoa memahami bahwa di dalam keselamatan perlu adanya pencurahan darah yang diwakili dengan hewan-hewan yang telah ditentukan. Konsep keselamatan tersebut memiliki kemiripan dengan konsep keselamatan dalam Perjanjian Lama yang kemudian disempurnakan dalam Perjanjian Baru yang mencakup makna teologis dari darah Yesus. Dengan demikian maka makna warna merah dalam tradisi Etnis Tionghoa dapat digunakan oleh orang Kristen sebagai jembatan komunikasi untuk memperkenalkan makna darah Yesus kepada etnis Tionghoa. 


\section{Daftar Pustaka}

Aliyanto, Deky Nofa. Diktat Dogma II Antropologi, Hamarteologi, Kristologi dan Sotereologi. Salatiga: STT Berea, 2018

Friberg, Timothy and Friberg, Barbara. Analytical Greek New Testament (GNM). 2nd ed. Timothy and Barbara Friberg, 1994. BibleWorks, v.10.

Gingrich, F. Wilbur Shorter Lexicon Of The Greek New Testament. 2nd ed. Frederick W. Danker (Chicago: University of Chicago Press, 1983), BibleWorks. v.10.

Hariyono, P. Kultur Cina Dan Jawa Pemahaman Menuju Asimilasi Kultur. Jakarta: Pustaka Sinar Harapan, 1994.

Hartono, Chris. Orang Tionghoa Dan Pekabaran Injil. Yogyakarta: Penerbit Taman Pustaka Kristen, 1996.

Indra, Icwei G. Allah - Manusia Sejati: Studi Ringkas Kristologi (Semarang: Pelayanan Kristen Mandiri "Mikhael").

Kwek, J.S. Mitologi Cina \& Kisah Alkitab. Yogyakarta: Penerbit Andi, 2011.

Ladd, Gerge Eldon. Teologi Perjanjian Baru Jilid 2. Bandung: Yayasan Kalam Hidup, 1999.

Moedjiono, Ragam Hias dan Warna Sebagai Simbol Dalam Arsitektur Cina. Modul Volume 11. No 1. 2011.

Panuju, Redi. Ilmu Budaya Dasar Dan Kebudayaan. Jakarta: Penerbit Gramedia Pustaka Utama, 1994.

Park, Yune Sun. Tafsiran Kitab Kejadian. Batu: Dept. Literatur YPPII, 2002.

Saptono, Andri. Pangu, Fuxi \& Nuwa Kisah-Kisah Mitologi China. Solo: Penerbit Katta, 2010.

Subagyo, Andreas S. Pengantar Riset Kuantitatif dan Kualitatif. Bandung: Yayasan Kalam Hidup, 2004.

Suryanto, Markus T. Feng shui/Hong Sui Dan Orang Kristen. Jakarta:Pelayanan Literatur Kristen Indonesia, 1995.
Suryanto, Markus T. Imlek Budaya Tionghoa dan Iman Kristen. Jakarta: Pelkrindo, 1999.

Susanto, Hasan. Perjanjian Baru Interlinier Yunani Indonesia dan Konkordansi Perjanjian Baru Jilid I. Jakarta: LAI, 2004

Susanto, Hasan. Perjanjian Baru Interlinier Yunani Indonesia dan Konkordansi Perjanjian Baru Jilid II. Jakarta: LAI, 2004 , Ensiklopedi Alkitab Masa Kini Jilid I. Jakarta: Yayasan Komunikasi Bina Kasih/OMF, 2002. , Ensiklopedi Alkitab Masa Kini Jilid II. Jakarta: Yayasan Komunikasi Bina Kasih/OMF, 2002.

http://alkitab.sabda.org 